\title{
CAPITAL ADEQUACY RATIO, NON PERFORMING LOAN, NET INTEREST MARGIN, BIAYA OPERASIONAL PENDAPATAN OPERASIONAL DAN LOAN TO DEPOSIT RATIO TERHADAP FINANCIAL DISTRESS
}

\author{
Baiq Defika Zahronyana \\ baiqdefiko@gmail.com \\ Dewa P.K Mahardika \\ Fakultas Ekonomi dan Bisnis, Universitas Telkom
}

diterima: 5/1/2018; direvisi: 19/3/2018; diterbitkan: 29/10/2018

\begin{abstract}
The purpose of this research is to determine the effect of CAR, NPL, NIM, BOPO, LDR on the fianancial distress of BUMN Commercial Bank either simultaneously or partially. BUMN Commercial Bank in 2012-2016 was selected as a research population. The purposive sampling technique was used for sampling and obtained samples as much of 4 companies with a five-year period every three months, resulting 80 data to be observed. The Model analysis in this research is logistic regression by using software SPSS 20. The results showed that the variables CAR,NPL,NIM,BOPO,LDR simultaneously affect the financial distress. Partially NPL,NIM, and BOPO variables don't have effect on financial distress, while CAR variable has significant negative has effect to financial distress and LDR variable significant positf has effect on financial distress.
\end{abstract}

Keywords: financial distress; CAR; NPL; NIM; BOPO; LDR

\begin{abstract}
Abstrak
Penelitian ini bertujuan untuk mengetahui pengaruh CAR, NPL, NIM, BOPO, LDR terhadap fianancial distress Bank Umum Badan Usaha Milik Negara (BUMN) baik secara simultan maupun parsial. Bank Umum BUMN tahun 2012-2016 dipilih sebagai populasi penelitian. Teknik purposive sampling digunakan untuk pengambilan sampel dan diperoleh sampel sebanyak 4 perusahaan dengan kurun waktu lima tahun secara triwulan, sehingga didapat 80 data yang diobservasi. Model analisis dalam penelitian ini adalah regresi logistik dengan menggunakan software SPSS 20. Hasil penelitian menunjukkan bahwa variabel CAR,NPL,NIM, BOPO dan LDR secara simultan berpengaruh terhadap financial distress. Secara parsial, variabel NPL,NIM, dan BOPO tidak berpengaruh terhadap financial distress sedangkan variabel CAR memiliki pengaruh negatif signifikan terhadap financial distress serta variabel LDR memiliki pengaruh positf signifikan terhadap financial distress.
\end{abstract}

Kata Kunci: financial distress, CAR, NPL, NIM, BOPO, LDR 


\section{PENDAHULUAN}

Keberadaan lembaga keuangan bank termasuk Bank Umum Badan Usaha Milik Negara sangatlah diperlukan sebagai penggerak perekonomian suatu negara, oleh sebab itu industri perbankan merupakan satu-satunya industri yang mendapat pengwasan dan penjaminan langsung dari pemerintah melalui lembaga OJK (Otoritas Jasa Keuangan) dan LPS (Lembaga Penjamin Simpanan).

Bank Umum Badan Usaha Milik Negara merupakan bank yang memiliki pengaruh besar terhadap industri perbankan di Indonesia yang mendominasi market share sebesar 34,95\% dan termasuk kedalam daftar 10 bank yang memiliki total aset terbesar di Indonesia (Gambar 1).

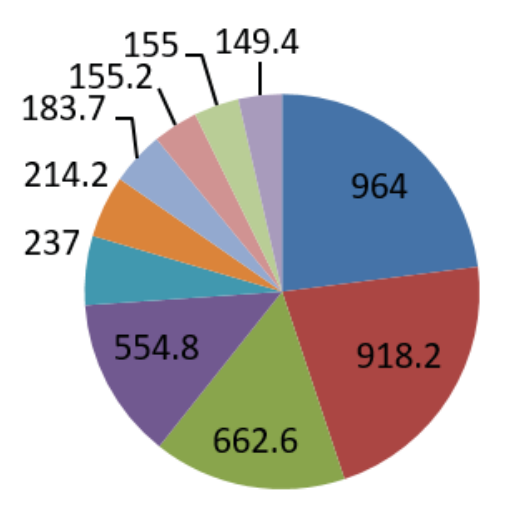

Sumber: Otoritas Jasa Keuangan, 2016

BRI
MANDIRI
BCA
BNI
CIMB NIAGA
BTN
PANIN
PERMATA

MAYBANK
Gambar 1. Daftar 10 Bank Terbesar di Indonesia Berdasarkan Aset (Dalam Triliun Rupiah) per 31 Desember 2016

Terjadinya krisis ekonomi global pada tahun 2008 memberikan dampak yang berlanjut hingga tahun tahun berikutnya. Adanya krisis ekonomi global tersebut menyebabkan penurunan kinerja perbankan termasuk kinerja Bank Umum BUMN. Menurut Marta (2016) yang disampaikan oleh para direktur utama bank BUMN bahwa melemahnya kinerja perbankan ini menyebabkan laju pertumbuhan kredit Bank Umum BUMN mengalami penurunan, pertumbuhan Bank BRI, BNI, BTN per akhir maret 2016 secara berturut-turut hanya sebesar $0.48 \%, 0.19 \%$, dan $2.87 \%$. Ditengah perlambatan laju kredit, pinjaman bermasalah (NPL) Bank Umum BUMN justru melonjak. Angka NPL Bank BRI naik dari $2.02 \%$ pada akhir 2015 menjadi $2.22 \%$ pada akhir maret 2016. Angka NPL Bank BNI mengalami kenaikan dari $2.7 \%$ menjadi $2.8 \%$. NPL Bank BTN juga mengalami kenaikan yaitu dari 3.42\% menjadi $3.59 \%$. Bahkan NPL Bank Mandiri meningkat tajam dari sebelumnya hanya sebesar $2.6 \%$ meningkat menjadi $4 \%$.

Perlambatan pertumbuhan ekonomi ini juga menyebabkan Bank Umum BUMN mengalami penurunan total laba. Hingga akhir tahun 2016, empat bank milik pemerintah ini hanya meraup total laba sebesar Rp 54,06 triliun atau turun sebesar $4.71 \%$ dari posisi $\mathrm{Rp} 56,73$ triliun di tahun 2015. Penurunan total laba bank milik pemerintah (BUMN) ini tidak terlepas dari catatan negatif PT. Bank Mandiri (Persero) Tbk. yang harus menerima penurunan laba hingga 32.1 \% dari Rp 20,33 triliun menjadi Rp 13,81 triliun. Penurunan laba yang dialami oleh PT. Bank Mandiri (Persero) Tbk, dikarenakan untuk menambah biaya pencadangan yang naik hingga $100 \%$ dari biaya pencadangan sebelumnya.

Laba merupakan salah satu indikator untuk mengukur kondisi kesehatan sebuah bank, oleh karena itu perbankan Indonesia dituntun untuk terus dapat mempertahankan kekuatan labanya sehingga kinerja keuangan bank akan selalu berada pada kondisi yang sehat. Dikarenakan apabila bank tidak dapat menghasilkan laba dengan optimal, maka akan berpengaruh terhadap kemampuan bank dalam menjalankan kegiatan operasionalnya, menghambat keberlangsungan usaha sebuah bank sehingga akan menghadapi kesulitan dalam berkembang. Bahkan jika hal tersebut berlangsung terus menerus bank dapat terindikasi mengalami kondisi kesulitan keuangan atau yang disebut juga dengan financial distress.

Menurut Brigham dan Daves (2009:868), financial distress merupakan kondisi dimana keuangan perusahaan dalam keadaan tidak sehat atau rawan kebangkrutan, dimulai ketika perusahaan tidak dapat memenuhi jadwal pembayaran atau ketika proyeksi arus kas yang mengindikasi bahwa perusahaan tersebut tidak dapat memenuhi kewajibannya. Beberapa model yang digunakan dalam memprediksi financial distress telah dikembangkan oleh para peneliti terdahulu, diantaranya diperkenalkan oleh Edward Altman pada tahun 1968, Springate tahun 1978, Ohlson tahun 1980, serta Zmijewski tahun 1983. Sampai saat ini penelitian masih banyak dilakukan untuk membandingkan mengenai model-model prediksi financial distress. Beberapa diantaranya dilakukan oleh Prabowo dan Wibowo (2015), Nurcahyanti (2015), serta oleh Thanjaya, Reno dan Saiful (2016) yang menganalisis mengenai ketepatan model Altman, Zmijewski, Springate dan Grover mereka berpendapat bahwa model Altman memiliki tingkat akurasi tertinggi dalam memprediksi financial distress.

Financial distress pada penelitian ini diukur dengan Altman Z-score yang telah dimodifikasi dimana model tersebut cocok digunakan untuk perusahaan yang bergerak dalam bidang non manufaktur salah satunya yaitu perusahaan jasa keuangan, adapun beberapa peneliti yang menggunakan model Altman Z-score modifikasi dalam memprediksi kesehatan bank diantaranya adalah Rohmah (2015) diikuti oleh penelitian Nainggolang (2017). 
Analisis financial distress yang menggunakan model Altman Z-score mengacu pada rasio-rasio keuangan. Harahap (2007:297). Dalam penelitian ini rasio keuangan diproksikan dalam Capital Adequacy Ratio (CAR), Non Performing Loan (NPL), Net Interest Margin (NIM), Biaya Operasional dan Pendapatan Operasional (BOPO), dan Loan to Deposit Ratio (LDR).

Menurut Tarmizi dan Wilyanto (2003:62) CAR merupakan rasio pemodalan yang menunjukkan kemampuan bank dalam menyediakan dana untuk keperluan pengembangan usaha dan menampung kemungkinan risiko kerugian yang diakibatkan dalam operasional bank. Beberapa peneliti terdahulu yaitu Paula Chrisna (2014), Qhairunnissa (2014), Kurniasari dan Ghozali (2013) berpendapat bahwa CAR tidak berpengaruh terhadap financial distress. Berbeda Sofiasani dan Gautama (2016), Rahmania dan Hermanto (2014), Almila dan Herdiningtyas (2005) yang berpendapat bahwa CAR memiliki pengaruh negatif signifikan terhadap financial distress, yang berarti bahwa semakin rendah CAR maka probabilitas terjadinya financial distress akan semakin tinggi.

Sesuai dengan Surat Edaran Bank Indonesia Nomor 3/30/DPNP Tanggal 14 Desember Tahun 2001 NPL merupakan kemampuan manajemen dalam mengelola kredit bermasalah yang diberikan oleh bank. Beberapa peneliti terdahulu yaitu Rahmania dan Hermanto (2014), Qhairunnissa (2014), Paula Chrisna (2014) berpendapat bahwa Non Performing Loan (NPL) memiliki pengaruh positif signifikan terhadap financial distress, ini menandakan bahwa semakin besar rasio NPL maka akan semakin besar juga probabilitas suatu bank untuk mengalami kondisi financial distress. Hal ini dikarenakan NPL menunjukkan tingginya angka kredit macet atau kredit bermasalah pada bank, semakin besar NPL hingga diatas rata-rata yang ditetapkan Bank Indonesia yaitu sebesar 5\% menunjukkan semakin buruknya kualitas kredit bank tersebut karena tingginya kredit bermasalah dan semakin tinggi risiko kredit yang harus dihadapi bank, sehingga bank akan memperbesar biaya pencadangan yang berpengaruh terhadap kinerja bank karena menurunkan laba yang diterima bank sehingga kemungkinan suatu bank mengalami financial distress semakin besar. Sedangkan Kurniasari dan Ghozali (2013) serta Almilia dan Herdiningtyas (2005) berpendapat bahwa NPL memiliki pengaruh tidak signifikan terhadap financial distress.

NIM menurut Pandia (2012:71) merupakan rasio yang digunakan untuk mengukur kemampuan manajemen bank dalam mengelola aktiva produktifnya untuk menghasilkan pendapatan bunga bersih. Beberapa peneliti terdahulu yaitu Qhairunnissa (2014), Rahmania dan Hermanto (2014), Bestari dan Rohman (2013) berpendapat bahwa Net Interest Margin (NIM) memiliki pengaruh negatif dan signifikan terhadap financial distress, yang berarti bahwa semakin tinggi
NIM akan menyebabkan semakin kecil probabilitas suatu bank dalam kondisi financial distress. Hal ini dikarenakan semakin tinggi NIM maka akan semakin baik. Berbeda dengan Almilia dan Herdiningtyas (2005) yang menyatakan bahwa Net Interest Margin (NIM) mempunyai pengaruh tidak signifikan terhadap financial distress dan pengaruhnya negatif.

Menurut Pandia (2012:72) BOPO adalah rasio yang digunakan untuk mengukur manajemen bank dalam mengendalikan biaya operasional terhadap pendapatan operasional. Beberapa peneliti terdahulu yaitu Rahmania dan Hermanto (2014), Kurnisari dan Ghozali (2013), Lestari (2009) berpendapat bahwa BOPO memiliki pengaruh signifikan terhadap financial distress dan pengaruhnya positif, yang berarti bahwa semakin tinggi BOPO maka semakin tinggi pula probabilitas suatu bank untuk mengalami kondisi financial distress. Berbeda dengan Qhairunnissa (2014), Paula Chrisna (2014) yang berpendapat bahwa Biaya Operasional Pendapatan Operasioanal (BOPO) tidak memiliki bengaruh terhadap financial distress.

Menurut Dendawijaya (2009:116) Loan to Deposit Ratio (LDR) adalah ukuran seberapa jauh kemampuan bank dalam membiayai kembali penarikan dana yang dilakukan deposan dengan mengandalkan kredit yang diberikan sebagai sumber likuiditasnya. Beberapa penelitian terdahulu yaitu Qhairunnissa (2014) yang berpendapat bahwa LDR tidak memiliki pengaruh yang signifikan terhadap kondisi financial distress. Berbeda dengan penelitian Rahmania dan Hermanto (2014), Sumantri dan Jurnali (2010) yang berpendapat bahwa LDR memiliki pengaruh positif signifikan terhadap financial distress, dikarenakan bank akan mengendalikan jumlah kredit yang lebih besar untuk membayar kembali penarikan yang dilakukan oleh nasabah. Sedangkan Achmad dan Kusumo (2003) menyatakan bahwa LDR memiliki pengaruh negatif signifikan.

\section{METODE}

Penelitian ini menggunakan dua jenis variabel, yaitu variabel bebas (terdiri dari rasio keuangan yang diproksikan dalam rasio CAR, NPL, NIM, BOPO dan LDR) dan variabel terikat yaitu (financial distress). Tujuannya adalah untuk mengetahui pengaruh CAR, NPL, NIM, BOPO, LDR terhadap financial distress Bank Umum Badan Usaha Milik Negara (BUMN) baik secara simultan maupun parsial. Operasionalisasi variabel ditunjukkan pada Tabel 1.

Bank Umum BUMN tahun 2012-2016 dipilih sebagai populasi penelitian. Teknik purposive sampling digunakan untuk pengambilan sampel dan diperoleh sampel sebanyak 4 perusahaan dengan kurun waktu lima tahun secara triwulan, sehingga didapat 80 data yang diobservasi. Berikut disajikan daftar sampel perbankan pada Tabel 2. 
Tabel 2. Daftar Sampel Perbankan

\begin{tabular}{cc}
\hline No & \multicolumn{1}{c}{ Nama Bank } \\
\hline 1 & Bank Negara Indonesia (Persero) Tbk. \\
2 & Bank Rakyat Indonesia (Persero) Tbk. \\
3 & Bank Tabungan Negara (Persero) Tbk. \\
4 & Bank Mandiri (Persero) Tbk. \\
\hline Sumber: Data yang telah diolah,2017
\end{tabular}

Model analisis adalah regresi logistik dengan menggunakan software SPSS 20. Karakteristik lainnya mengenai penelitian ini dimuat pada Tabel 3.

Tabel 3. Karakteristik Penelitian

\begin{tabular}{cll}
\hline No & \multicolumn{1}{c}{ Karakteristik Penelitian } & \multicolumn{1}{c}{ Jenis } \\
\hline 1 & Berdasarkan metode & Kuantitatif \\
2 & Berdasarkan tujuan & Deskriptif dan Verifikatif \\
3 & Berdasarkan tipe penyidikan & Kausal \\
4 & Berdasarkan keterlibatan peneliti & Tidak mengintervensi data \\
5 & Berdasarkan unit analisis & Group (kelompok) \\
6 & Berdasarkan waktu pelaksanaan & Gabungan (panel data) \\
\hline
\end{tabular}

\section{HASIL}

Hasil analisis deskriptif variabel operasional ditunjukkan pada Tabel 4.

Tabel 4. Hasil Pengujian Statistik Deskriptif CAR, NPL, NIM, BOPO, LDR

\begin{tabular}{lrrrrr}
\hline \multicolumn{5}{c}{ Statistik Deskriptif } \\
\hline CAR & 80 & 14,3312 & 22,9075 & 17,5581 & 2,0918 \\
NPL & 80 & 1,5477 & 5,0110 & 2,7783 & 0,9870 \\
NIM & 80 & 3,4499 & 9,0599 & 6,3052 & 1,3218 \\
BOPO & 80 & 59,9286 & 89,9092 & 72,3075 & 8,6992 \\
LDR & 80 & 73,6141 & 110,9670 & 90,4713 & 10,2061 \\
Financial & 80 & 0,20 & 2,38 & 1,3316 &, 55561 \\
distress & & & & & \\
Valid N & 80 & & & & \\
(listwise) & & & & & \\
\hline
\end{tabular}

Sumber: Hasil output SPSS.20, 2017

Pada Tabel 4 menggambarkan hasil uji deskriptif Capital Adequacy Ratio yang dilakukan pada Bank Umum Badan Usaha Milik Negara periode 2012-2016 per triwulan menunjukkan bahwa nilai minimum CAR sebesar 14,3321 dimiliki oleh Bank Tabungan Negara Tbk. (BBTN) periode tahun 2013 triwulan III. Nilai maksimum CAR adalah sebesar 22,9075 yang dimiliki oleh Bank Rakyat Indonesia Tbk. (BBRI) periode tahun 2016 triwulan IV. Nilai rata-rata CAR sebesar 17,5581 sedangkan nilai standar deviasi sebesar 2,0918.
Nilai rata-rata CAR lebih besar daripada nilai standar deviasi, hal ini menunjukkan bahwa data CAR ini tidak bervariasi atau data berkelompok. Nilai CAR yang mengalami penurunan sebanyak 44 data dan sebanyak 36 data mengalami kenaikan nilai CAR selain itu juga berdasarkan Surat Edaran Bank Indonesia No. 6/23/DPNP Tahun 2004 maka nilai CAR yang berada di atas rata-rata ATMR atau dalam kriteria sehat sebanyak 80 data, akan tetapi adanya nilai CAR yang mengalami penurunan lebih besar dari pada nilai CAR yang mengalami peningkatkan dapat mengakibatkan semakin besarnya probabilitas terjadinya financial distress dikarenakan modal yang dikeluarkan untuk membiayai aktiva rata-rata tertimbang menurut risiko akan semakin besar.

Tabel 4 menggambarkan hasil uji deskriptif Non Performing Loan yang dilakukan pada Bank Umum Badan Usaha Milik Negara periode 2012-2016 per triwulan menunjukkan bahwa nilai minimum NPL sebesar 1,5547 dimiliki oleh Bank Rakyat Indonesia Tbk. (BBRI) periode tahun 2013 triwulan IV. Nilai maksimum NPL adalah sebesar 5,0110 yang dimiliki oleh Bank Tabungan Negara Tbk. (BBTN) periode tahun 2014 triwulan II. Nilai rata-rata NPL sebesar 2,7783 sedangkan nilai standar deviasi sebesar 0,9870. Rata-rata NPL lebih besar daripada standar deviasi, menunjukkan NPL dalam penelitian ini tidak bervariasi atau data berkelompok. Nilai NPL yang mengalami penurunan sebanyak 52 data dan sebanyak 28 data mengalami kenaikan nilai NPL selain itu juga berdasarkan Surat Edaran Bank Indonesia No. 6/23/DPNP Tahun 2004 maka nilai NPL yang berada dalam kriteria sehat (non financial distress) sebanyak 80 data. Nilai NPL yang mengalami penurunan lebih besar dari pada nilai NPL yang mengalami peningkatkan berarti bahwa probablitas terjadinya financial distress semakin rendah dikarenakan biaya yang dikeluarkan bank untuk menanggung kredit bermasalah akan semakin berkurang.

Tabel 4 menggambarkan hasil uji deskriptif Net Interest Margin yang dilakukan pada Bank Umum Badan Usaha Milik Negara periode 2012-2016 per triwulan menunjukkan bahwa nilai minimum NIM sebesar 3,4499 dimiliki oleh Bank Tabungan Negara Tbk. (BBTN) periode tahun 2013 triwulan III. Nilai maksimum NIM adalah sebesar 9,0599 yang dimiliki oleh Bank Rakyat Indonesia Tbk. (BBRI) periode tahun 2014 triwulan I. Rata-rata NIM sebesar 6,3052 sedangkan nilai standar deviasi sebesar 1,3218. Rata-rata NIM lebih besar daripada nilai standar deviasi, hal ini menunjukkan NIM dalam penelitian ini tidak bervariasi atau data berkelompok. Nilai NIM yang mengalami penurunan sebanyak 37 data dan sebanyak 43 data mengalami kenaikan nilai NIM selain itu juga berdasarkan Surat Edaran Bank Indonesia No. 6/23/DPNP Tahun 2004 maka nilai NIM yang berada dalam kriteria sehat (non financial distress) sebanyak 80 data. Nilai NIM yang mengalami penurunan lebih rendah dari pada nilai NIM 
yang mengalami peningkatkan berarti bahwa probablitas terjadinya financial distress semakin rendah dikarenakan semakin rendah NIM maka pendapatan bunga atas pengelolaan aktiva produktif semakin berkurang.

Tabel 4 menggambarkan hasil uji deskriptif Biaya Operasional Pendapatan Operasional (BOPO) yang dilakukan pada Bank Umum Badan Usaha Milik Negara periode 2012-2016 per triwulan menunjukkan bahwa nilai minimum BOPO sebesar 59,9286 dimiliki oleh Bank Rakyat Indonesia Tbk. (BBRI) periode tahun 2012 triwulan IV. Nilai maksimum BOPO adalah sebesar 89,9092 yang dimiliki oleh Bank Tabungan Negara Tbk. (BBTN) periode tahun 2014 triwulan III. Nilai rata-rata BOPO sebesar 72,3075 sedangkan nilai standar deviasi sebesar 8,6992. Rata-rata BOPO lebih besar daripada nilai standar deviasi, menunjukkan bahwa BOPO tidak bervariasi atau data berkelompok. Nilai BOPO yang mengalami penurunan sebanyak 36 data dan sebanyak 44 data mengalami kenaikan nilai BOPO selain itu juga berdasarkan Surat Edaran Bank Indonesia No. 6/23/ DPNP Tahun 2004 maka nilai BOPO yang berada dalam kriteria sehat (non financial distress) sebanyak 80 data. Nilai BOPO yang mengalami penurunan lebih besar dari pada nilai BOPO yang mengalami peningkatkan berarti bahwa probablitas terjadinya financial distress semakin meningkat, akan tetapi hal ini tidak konsisiten dengan penentapan penilaian tingkat kesehatan bank berdasarkan berdasarkan Surat Edaran Bank Indonesia No. 6/23/ DPNP Tahun 2004 yang menyatakan bahwa sebanyak 80 data BOPO dalam kriteria sehat (non financial distress).

Tabel 4 menggambarkan hasil uji deskriptif Loan to Deposit Ratio yang dilakukan pada Bank Umum Badan Usaha Milik Negara periode 2012-2016 per triwulan menunjukkan bahwa nilai minimum LDR sebesar 73,6141 dimiliki oleh Bank Negara Indonesia Tbk. (BBNI) periode tahun 2012 triwulan II. Nilai maksimum LDR adalah sebesar 110,9670 yang dimiliki oleh Bank Tabungan Negara Tbk. (BBTN) periode tahun 2016 triwulan III. Nilai rata-rata LDR sebesar 90,4713 sedangkan nilai standar deviasi sebesar 10,2061. Rata-rata LDR lebih besar daripada nilai standar deviasi, menunjukkan bahwa LDR ini tidak bervariasi atau data berkelompok. Nilai LDR yang mengalami penurunan sebanyak 34 data dan sebanyak 46 data mengalami kenaikan nilai LDR selain itu juga berdasarkan Surat Edaran Bank Indonesia No. 6/23/DPNP Tahun 2004 maka nilai LDR yang berada dalam kriteria sehat (non financial distress) sebanyak 28 data dan sebanyak 42 data dalam kriteria tidak sehat (financial distress). Semakin besar nilai LDR maka probabilitas terjadinya financial distress akan semakin besar dikarenakan bank akan mengendalikan jumlah kredit yang lebih besar untuk membayar kembali penarikan yang dilakukan oleh nasabah.

Tabel 4 menggambarkan hasil deskriptiffinancial distress yang dilakukan pada Bank Umum Badan Usaha Milik Negara periode 2012-2016 per triwulan menunjukkan nilai minimum financial distress sebesar
0,20 dimiliki oleh Bank Tabungan Negara Tbk. (BBTN) periode tahun 2016 triwulan 1. Nilai maksimum financial distress adalah sebesar 2,38 dimiliki oleh Bank Rakyat Indonesia Tbk. (BBRI) periode tahun 2014 triwulan IV. Rata-rata financial distress sebesar 1,3316 sedangkan nilai standar deviasi sebesar 0,5556, menunjukkan bahwa data LDR dalam penelitian ini tidak bervariasi atau data berkelompok.

Hasil ketepatan pengujian financial distress ditunjukkan dalam Tabel 5.

Tabel 5. Hasil Ketepatan Pengujian Financial distress (Classification Table ${ }^{\mathrm{a}}$ )

\begin{tabular}{|c|c|c|c|c|c|c|}
\hline \multicolumn{7}{|c|}{ Classification Table ${ }^{\mathrm{a}}$} \\
\hline & \multirow{2}{*}{\multicolumn{3}{|c|}{ Observed }} & \multicolumn{3}{|c|}{ Predicted } \\
\hline & & & & \multicolumn{2}{|c|}{ Indicator } & \multirow{2}{*}{$\begin{array}{c}\text { Percentage } \\
\text { Correct }\end{array}$} \\
\hline & Status & & $\begin{array}{l}\text { Number of } \\
\text { observations }\end{array}$ & 1 & 0 & \\
\hline \multirow[t]{3}{*}{ Step 1} & Indicator & 1 & 63 & 62 & 1 & 98,4 \\
\hline & & 0 & 17 & 4 & 13 & 76,5 \\
\hline & Overall $\mathrm{P}$ & rcent & age & & & 93,8 \\
\hline
\end{tabular}

Sumber: Data yang telah diolah, 2017

Pada Tabel 5 terlihat bahwa nilai prediksi untuk kondisi sampel yang mengalami kondisi non financial distress sebanyak 63 unit sampel dan sampel dalam kondisi financial distress sebanyak 17 unit sampel. Sedangkan klasifikasi pada kolom prediksi status terlihat bahwa sampel yang mengalami kondisi non financial distress sebanyak 62 unit sampel dan sampel yang mengalami kondisi financial distress sebanyak 13 unit sampel dengan ketepatan prediksi yang diamati untuk sampel dalam kondisi non financial distress sebesar 98,4\% dan untuk sampel dalam kondisi financial distress sebesar 76,5 $\%$ dengan keseluruhan hasil klasifikasi menunjukkan presentase ketepatan klasifikasi sebesar 93,8\%.

Hasil pegujian regresi logistik ditunjukkan pada Tabel 6.

Tabel 6. Hosmer and Lemeshow Test

\begin{tabular}{cccc}
\hline \multicolumn{4}{c}{ Hosmer and Lemeshow Test } \\
\hline Step & Chi-square & $\mathrm{df}$ & Sig. \\
\hline 1 & 1,087 & 8 &, 998 \\
\hline
\end{tabular}

Sumber: Data yang telah diolah, 2017

Tabel 6 menunjukkan nilai Chi-square sebesar 1,087 dengan nilai signifikansi sebesar 0,998. Berarti model regresi yang digunakan fit dengan data sehingga dapat digunakan untuk analisis selanjutnya.

Tabel 7. Iteration History

\begin{tabular}{cc}
\hline Iteration & -2Log Likelihood \\
\hline Step $_{0}$ & 106,819 \\
Step $_{1}$ & 36,149 \\
\hline Sumber: Data yang telah diolah,2017
\end{tabular}


Dari Tabel 7 dapat dilihat bahwa -2Log Likelihood awal memiliki nilai sebesar 106,819 dan nilai akhir sebesar 36,149. Berarti terjadi penurunan nilai -2Log Likelihood menunjukkan model regresi yang semakin baik. Dengan demikian $\mathrm{H}_{0}$ diterima, dikarenakan model tersebut fit dengan data (Santoso, 2014).

Hasil Pengujian koefisien regresi, ditunjukkan pada Tabel 8.

\begin{tabular}{cccc}
\multicolumn{4}{c}{ Tabel 8. Model Summary } \\
\hline \multirow{4}{*}{ Hosmer and Lemeshow Test } \\
\hline \multirow{2}{*}{ Step } & -2 Log & Cox \& Snell R & Nagelkerke R \\
& likelihood & Square & Square \\
\hline 1 & $36,149^{\text {a }}$ &, 587 &, 796 \\
\hline
\end{tabular}

Sumber: Data yang telah diolah, 2017

Berdasarkan Tabel 8 dapat dilihat nilai Nagelkerke R Square sebesar 0,796 dan nilai Cox \& Snell R Square sebesar 0,587. Berarti variabel independen yaitu CAR, NPL, NIM, BOPO dan LDR memiliki kemampuan untuk memengaruhi variabel dependen yaitu financial distress sebesar 0.796 atau 79,6\% selebihnya sebesar $20,4 \%$ dipengaruhi oleh faktor-faktor lain di luar variabel yang digunakan.

Tabel 9. Omnibus Tests of Model Coefficients

\begin{tabular}{llccc}
\hline \multicolumn{5}{c}{ Omnibus Tests of Model Coefficients } \\
\hline \multirow{3}{*}{ Step 1 } & Chi-square & df & Sig. \\
& Step & 70,669 & 5 &, 000 \\
& Block & 70,669 & 5 &, 000 \\
& Model & 70,669 & 5 &, 000 \\
\hline
\end{tabular}

Sumber: Data yang telah diolah,2017

Berdasarkan Tabel 9 dapat dilihat bahwa nilai Chisquare adalah sebesar 70,669 dan degree of freedom sebesar 5 , serta signifikansi atau p-value adalah sebesar 0,000. Kondisi ini berarti CAR, NPL, NIM, BOPO, dan LDR secara bersama-sama memiliki pengaruh untuk memprediksi kondisi financial distress pada Bank Umum Badan Usaha Milik Negara (BUMN).

Tabel 10. Variables in the Equation

\begin{tabular}{llrrrrrr}
\hline \multicolumn{7}{c}{ Variables in the Equation } \\
\hline \multicolumn{1}{c}{ B } & S.E. & Wald & df & Sig. & Exp(B) \\
\hline Step 1 $^{\text {a }}$ & CAR &,- 010 &, 004 & 5,941 & 1 &, 015 &, 990 \\
& NPL &, 018 &, 016 & 1,256 & 1 &, 262 & 1,018 \\
& NIM &,- 007 &, 007 &, 950 & 1 &, 330 &, 993 \\
& BOPO &, 001 &, 002 &, 715 & 1 &, 398 & 1,001 \\
& LDR &, 003 &, 002 & 4,667 & 1 &, 031 & 1,003 \\
& Constant & $-20,870$ & 9,862 & 4,479 & 1 &, 034 &, 000 \\
\hline
\end{tabular}

Sumber: Data yang telah diolah,2017

Berdasarkan pengujian regresi pada Tabel 10, dapat dibuat persamaan penelitian sebagai berikut:

$$
\begin{aligned}
\operatorname{Ln} \frac{P}{(1-P)}= & -20,870-0,010\left(X_{1}\right)+0,018\left(X_{2}\right)-0.007\left(X_{3}\right) \\
& +0,001\left(X_{4}\right)+0.003\left(X_{5}\right)+e
\end{aligned}
$$

Keterangan :

$$
\begin{array}{cll}
\operatorname{Ln} \frac{\mathrm{P}}{(1-\mathrm{P})} & : & \text { Financial distress } \\
\mathrm{X}_{1} & : & \text { Capital Adequacy Ratio } \\
\mathrm{X}_{2} & : & \text { Non Performing Loan } \\
\mathrm{X}_{3} & : & \text { Net Interest Margin } \\
\mathrm{X}_{4} & : & \text { Beban Operasional Pendapatan Operasional } \\
\mathrm{X}_{5} & : & \text { Loan to Deposit Ratio } \\
\mathrm{e} & : & \text { Error }
\end{array}
$$

Nilai Konstanta adalah sebesar -20,870, hal tersebut menunjukkan bahwa tanpa adanya pengaruh dari variabel bebas yaitu CAR, NPL, NIM, BOPO maka perusahaan berada dalam kategori non financial distress karena memiliki skor sebesar -20,870.

Capital Adequacy Ratio (CAR) memiliki koefisien sebesar -0,010 dan tingkat signifikansi sebesar 0,015, menunjukkan bahwa CAR memiliki pengaruh signifikan terhadap financial distress. Non Performing Loan (NPL) memiliki koefisien sebesar 0,018 sedangkan tingkat signifikansi sebesar 0,262, menunjukkan bahwa NPL tidak memiliki pengaruh signifikan terhadap financial distress. Net Interest Margin (NIM) memiliki koefisien sebesar -0,007 sedangkan tingkat signifikansi sebesar 0,330 , menunjukkan bahwa NIM tidak memiliki pengaruh signifikan terhadap financial distress.

Biaya Operasional Pendapatan Operasional (BOPO) memiliki koefisien sebesar 0,001 sedangkan tingkat signifikansi sebesar 0,398, menunjukkan bahwa BOPO tidak memiliki pengaruh signifikan terhadap financial distress. Loan to Deposit Ratio (LDR) memiliki koefisien sebesar 0,003 sedangkan tingkat signifikansi sebesar 0,031, menunjukkan bahwa LDR memiliki pengaruh signifikan terhadap financial distress.

\section{PEMBAHASAN}

Berdasarkan hasil pengujian secara simultan ditemukan bahwa CAR, NPL, NIM, BOPO, dan LDR secara bersama-sama memiliki pengaruh untuk memprediksi kondisi financial distress pada Bank Umum Badan Usaha Milik Negara (BUMN).

Berdasarkan hasil pengujian secara parsial bahwa variabel CAR memiliki nilai koefisien regresi yang negatif sebesar -0,010 dengan siginifikansi 0.015 . Berarti CAR secara parsial berpengaruh signifikan terhadap financial distress dan memiliki arah negatif, yang berarti bahwa semakin rendah ratio ini, maka akan semakin besar probabilitas suatu bank untuk 
mengalami kondisi financial distress sesuai dengan hasil pengolahan data yang dilakukan di Bank Umum Badan Usaha Milik Negara (BUMN) periode 2012-2016, data yang diolah berjumlah 80 data yang dimana terdapat nilai CAR yang mengalami penurunan sebesar 44 data dan sisanya sebanyak 36 data mengalami peningkatan. Nilai CAR yang mengalami penurunan lebih besar dari pada nilai CAR yang mengalami peningkatan, ini berarti bahwa modal yang digunakan untuk menanggung aktiva rata-rata menurut risiko akan semakin besar sehingga menyebabkan probabilitas terjadinya financial distress akan semakin besar. Hasil tersebut sesuai dengan hipotesis yang dibangun peneliti.

Berdasarkan hasil pengujian secara parsial bahwa variabel NPL memiliki nilai signifikansi sebesar 0,262. Berarti Non Performing Loan (NPL) secara parsial tidak berpengaruh terhadap financial distress. Nilai koefisien regresi sebesar 0,018 yang memiliki nilai positif ini menandakan bahwa semakin besar rasio NPL maka akan semakin besar juga probabilitas suatu bank untuk mengalami kondisi financial distress. NPL yang tidak berpengaruh dikarenakan pada hasil pengolahan data didapatkan hasil bahwa sebanyak 80 data yang diolah sebesar $100 \%$ dari data termasuk dalam kriteria sehat (non financial distress) berdasarkan kriteria penilaian yang terdapat dalam Surat Edaran Bank Indonesia juga dari 80 data yang diolah sebanyak 52 data mengalami penurunan nilai NPL dan sisanya sebanyak 28 mengalami kenaikan nilai NPL, adanyanya nilai NPL yang menurun lebih besar dari pada jumlah nilai NPL yang mengalami peningkatan ini menunjukkkan bahwa probabilitas terjadinya financial distress akan semakin kecil dikarenakan biaya yang dikeluarkan oleh Bank Umum BUMN dalam membiayai kredit bermasalahnya akan semakin kecil, oleh adanya faktor-faktor tersebut sehingga menyebabkan NPL secara parsial tidak memiliki pengaruh yang signifikan terhadap financial distress. Hasil tersebut tidak sesuai dengan hipotesis yang dibangun peneliti.

Berdasarkan hasil pengujian secara parsial bahwa variabel NIM memiliki nilai nilai signifikansi sebesar 0,330. Berarti Net Interest Margin (NIM) secara parsial tidak berpengaruh terhadap financial distress nilai koefisien regresi sebesar -0,007, arah koefisien dalam penelitian ini bertanda negatif, yang berarti bahwa semakin tinggi NIM akan menyebabkan semakin kecil probabilitas suatu bank dalam kondisi financial distress. NIM yang tidak berpengaruh dikarenakan pada hasil pengolahan data didapatkan hasil bahwa nilai NIM yang mengalami penurunan sebanyak 37 data dan sebanyak 43 data mengalami kenaikan nilai NIM selain itu juga berdasarkan Surat Edaran Bank Indonesia maka nilai NIM yang berada dalam kriteria sehat (non financial distress) sebanyak 80 data atau dapat dikatakan 100 $\%$ data dalam kriteria sehat (non financial distress). Nilai NIM yang mengalami penurunan lebih rendah dari pada nilai NIM yang mengalami peningkatkan berarti bahwa probablitas terjadinya financial distress semakin rendah dikarenakan semakin rendah NIM maka pendapatan bunga atas pengelolaan aktiva produktif semakin berkurang, oleh adanya faktor-faktor tersebut sehingga menyebabkan NIM secara parsial tidak memiliki pengaruh yang signifikan terhadap financial distress. Hasil tersebut tidak sesuai dengan hipotesis yang dibangun peneliti.

Berdasarkan hasil pengujian secara parsial bahwa variabel BOPO memiliki nilai signifikansi sebesar 0,398. Berarti Biaya Operasional Pendapatan Operasional (BOPO) secara parsial tidak berpengaruh terhadap financial distress. Nilai koefisien regresi sebesar 0,001 , arah koefisien dalam penelitian ini bertanda positif, yang berarti bahwa semakin tinggi BOPO akan semakin tinggi pula probabilitas suatu bank untuk mengalami kondisi financial distress. BOPO tidak berpengaruh berdasarkan Surat Edaran Bank Indonesia maka nilai BOPO yang berada dalam kriteria sehat (non financial distress) sebanyak 80 data ini berarti $100 \%$ dari data yang diolah tidak dalam kondisi bermasalah (financial distress). Hasil tersebut tidak sesuai dengan hipotesis yang dibangun peneliti.

Variabel Loan to Deposit Ratio (LDR) menunjukkan nilai koefisien regresi sebesar 0,003 , arah koefisien penelitian ini bertanda postif yang berarti bahwa semakin besar LDR akan menyebabkan semakin besar probabilitas suatu bank untuk mengalami kondisi financial distress. Nilai siginifikansi LDR sebesar 0.031, Berarti Loan to Deposit Ratio (LDR) secara parsial berpengaruh signifikan terhadap financial distress dan pengaruhnya positif. LDR yang memiliki pengaruh terhadap financial distress ini didukung dengan hasil dari pengolahan data yang dimana didapatkan hasil yaitu nilai LDR yang mengalami penurunan sebanyak 34 data dan sebanyak 46 data mengalami kenaikan nilai LDR selain itu juga berdasarkan Surat Edaran Bank Indonesia maka nilai LDR yang berada dalam kriteria sehat (non financial distress) sebanyak 28 data dan sebanyak 42 data dalam kriteria tidak sehat (financial distress). Semakin besar nilai LDR ini maka probabilitas terjadinya financial distress akan semakin besar dikarenakan bank akan mengendalikan jumlah kredit yang lebih besar untuk membayar kembali penarikan yang dilakukan oleh nasabah. Hasil tersebut sesuai dengan hipotesis yang dibangun peneliti.

\section{KESIMPULAN}

Penelitian ini menunjukkan bahwa berdasarkan hasil pengujian statistik deskriptif variabel CAR, NPL,NIM, BOPO, LDR dan Financial distress memiliki data yang tidak bervariasi atau data kelompok dengan ketepatan pengujian financial distress sebesar 93,8\%. CAR, NPL, NIM, BOPO dan LDR secara simultan berpengaruh terhadap financial distress Bank Umum Badan Usaha Milik Negara (BUMN) periode 2012- 
2016. Secara parsial, Capital Adequacy Ratio (CAR) berpengaruh negatif signifikan. Non Performing Loan (NPL), Net Interest Margin (NIM), Biaya Operasional Pendapatan Operasional (BOPO) tidak berpengaruh, sedangkan Loan to Deposit Ratio (LDR) berpengaruh positif signifikan terhadap financial distress Bank Umum Badan Usaha Milik Negara (BUMN) periode 2012-2016.

\section{DAFTAR PUSTAKA}

Achmad, T., dan Kusomo, W.K. 2003. Analisis Rasio-Rasio Keuangan sebagai Indikator dalam Memprediksis Potensi Kebangkrutan Perbankan di Indonesia. Jurnal Ekonomi \& Bisnis Vol.15 No.1 Juni 2003.

Almilia, dan Herdiningtyas, W. 2005. Analisis Rasio CAMEL terhadap Prediksi Kondisi Bermasalah pada Lembaga Perbankan periode 2000-2002. Jurnal Akuntansi dan Keuangan Vol.7 No.2 November 2005,ISSN: 1411-0288, E-ISSN:2338-8137,131-147.

Bank Indonesia (BI). 2001. Surat Edaran Bank Indonesia Nomor 3/30/DPNP Tahun 2001 tentang Laporan Keuangan Publikasi Triwulan dan Bulanan Bank Umum serta Laporan Tertentu yang Disampaikan kepada Bank Indonesia. Retrived September 23, 2017, from http://www.bi.go.id/id/peraturan/ perbankan/Pages/SE\%20No.13-30-DPNP.aspx

Bank Indonesia (BI). 2004. Surat Edaran Bank Indonesia Nomor 6/23/DPNP Tahun 2004 tentang Sistem Penilaian Tingkat Kesehatan Bank Umum. Retrived September 25, 2017, from http://www.bi.go.id/ $\mathrm{id} /$ peraturan/perbankan/Pages/ketentuan $\% 20$ perbankan.aspx

Bestari, A.R., dan Rohman A. 2013. Pengaruh Rasio Camel dan Ukuran Bank terhadap Prediksi Kondisi Bermasalah pada Sektor Perbankan yang Terdaftar di BEI periode 2007-2011. Jurnal Akuntansi Diponegoro Vol.2 No.3 Tahun 2013, ISSN: 23373806, 1-9.

Brigham, E.F., \& Daves, P.R 2009. Intermediete Financial Management with Thomson One. United States of America: Cengage South-Western.

Darsono dan Ashari. 2005. Pedoman Praktis Memahami Laporan Keuangan. Jakarta: Salemba Empat.

Dendawijaya, L. 2009. Manajemen Perbankan. Jakarta: Ghalia Indonesia.

Ghozali, dan Kurniasari, C. 2013. Analisis Pengaruh Rasio CAMEL dalam Memprediksi Financial distress Perbankan Indonesia. Diponegoro Journal of Accounting Vol.2 No.4 Tahun 2013, ISSN: 23373806, 1-10.

Harahap, S.S. 2007. Analisis Kritis Atas Laporan Keuangan. Jakarta: PT. Raja Grafindo Persada.

Lestari, V.D. 2009. Analisa Tingkat Kesehatan Bank-
Bank Pemerintah dengan Menggunakan Metode CAMELS dan Analisis Deskriman Periode 20062008. Fakultas Ekonomi: Universitas Gunadarma.

Marta, M.F. 2016. Kinerja Bank BUMN, Laba Stagnan, Kredit Bermasalah Melonjak. Retrived September 11, 2017, from http://ekonomi.kompas.com/ $\mathrm{read} / 2016 / 05 / 09 / 072514726 /$ Kinerja.Bank.BUMN. Laba.Stagnan.Kredit.Bermasalah.Melonjak

Nainggolan, H. 2017. Analisis Resiko Keuangan dengan Model Altman Z-Score pada Perusahaan Perbankan di Indonesia (Listed di Bursa Efek Indonesia). Jurnal Ilmiah Akuntansi dan Keuangan Vol.6 No.1 Juli 2017.

Nurcahyati, W. 2015. Studi Komparatif Model Z-Score Altman, Springate dan Zmijewski dalam Mengidentifikasi Kebangkrutan Perusahaan yang Terdaftar di BEI. Jurnal Akuntansi Vol.3 No.1 Tahun 2015.

Otoritas Jasa Keuangan. 2016. Statistik Perbankan Indonesia. Retrived September 10, 2017, from dari http://www.ojk.go.id/id/kanal/perbankan/data-danstatistik/statistik-perbankan-indonesia/default.aspx

Pandia, F. 2012. Manajemen Dana dan Kesehatan Bank. Jakarta: Rineka Cipta.

Paula Chrisna., dan Ismawati, K. 2014. Analisis Pengaruh Rasio CAMEL dalam Mendeteksi Financial distress pada Perusahaan Perbankan yang Terdaftar di BEI. Surakarta: Universitas Surakarta.

Prabowo, R., dan Wibowo. 2015. Analisis Perbandingan Model Altman Z-Score, Zmijewski, dan Springate dalam Memprediksi Kebangkrutan Perusahaan Delisting di BEI Periode 2008-2013. Jurnal Akuntansi, Keuangan dan Perbankan, ISSN: 2338-9753 Vol.1 No.3 Juni 2015, ISSN:2338-9753, 195-203.

Qhairunnissa, N.A. 2014. Analisis Pengaruh Rasio CAMELS Terhadap Prediksi Kondisi Bermasalah pada Bank Umum yang Terdaftar di Bursa Efek Indonesia periode 2007-2012. E Journal Telkom University.

Rahmania, Meilita Fitri., dan Hermanto, Suwardi Bambang. 2014. Analisis Rasio Keuangan Terhadap Financial Distress Perusahaan Perbankan Studi Empiris di BEI 2010-2012. Jurnal Ilmu \& Riset Akuntansi, 3 (1), h: 1-20.

Rohmah, S. 2015. Analisis Prediksi Potensi Financial distress pada Bank Umum Syariah Menurut Metode Altman Z-Score (Periode 2012-2013). Prosiding Keuangan dan Perbankan Syariah Vol.1 No.1 Februari 2015.

Santoso, S. 2014. Panduan Lengkap SPSS Versi 20 Edisi Revisi. Jakarta: Gramedia.

Sofiasani, G. dan Gautama, B.P. 2016. Pengaruh CAMEL Terhadap Financial distress pada Sektor Perbankan Indonesia periode 2009-2013. Journal of Business Management and Enterpreneurship Education Vol.1 No.1 April 2016. 
Sumantri dan Jurnali, T. 2010. Manfaat Rasio Keuangan dalam Memprediksis Kepailitan Bank Nasional. Jurnal Bisnis dan Akuntanasi Vol.12 No.1 April 2010.

Tarmizi, A., dan Willyanto, K. 2003. Analisis Rasio-Rasio Keuangan sebagai Indikator dalam Memprediksi Potensi Kebangkrutan Perbankan di Indonesia. Jurnal Media Ekonomi dan Bisnis Vol.
15 No. 1 Juni 2003.

Taswan. 2010. Manajemen Perbakan, Konsep dan Aplikasi. Yogyakarta: UPP STIM YKPN.

Thanjaya., Reno., dan Saiful. 2016. Analisa Kegunaan Model Altman, Grover dan Zmijewski untuk Memprediksi Financial distress. Bengkulu: Universitas Bengkulu.

Tabel 1 Operasionalisasi Variabel

\begin{tabular}{|c|c|c|}
\hline Variabel dan Definisi Variabel & Skala & Indikator \\
\hline \multicolumn{3}{|c|}{ Variabel Independen (X) } \\
\hline \multirow{2}{*}{$\begin{array}{l}\text { Capital Adequacy Ratio (CAR) merupakan perbandingan } \\
\text { modal bank dengan Aktiva Tertimbang Menurut Risiko } \\
\text { (Taswan, 2010:166) }\end{array}$} & \multirow[t]{2}{*}{ Rasio } & \multirow{2}{*}{$\mathrm{CAR}=\frac{\text { Modal }}{\mathrm{ATMR}}$} \\
\hline & & \\
\hline \multirow{2}{*}{$\begin{array}{l}\text { Non Performing Loan (NPL) adalah perbandingan } \\
\text { antara kredit bermasalah terhadap total kredit. (Taswan, } \\
\text { 2010:166) }\end{array}$} & \multirow[t]{2}{*}{ Rasio } & \multirow{2}{*}{$\mathrm{NPL}=\frac{\text { Kredit Bermasalah }}{\text { Total Kredit }} \times 100 \%$} \\
\hline & & \\
\hline \multirow{2}{*}{$\begin{array}{l}\text { Net Interest Margin (NIM) adalah rasio yang digunakan } \\
\text { untuk mengukur kemampuan manajemen bank dalam } \\
\text { mengelola aktiva produktifnya untuk menghasilkan } \\
\text { pendapatan bunga bersih (Pandia, 2012:71) }\end{array}$} & \multirow[t]{2}{*}{ Rasio } & \multirow{2}{*}{$\mathrm{NIM}=\frac{\text { Pendapatan Bunga Bersih }}{\text { Total Aset Produktif }} \times 100 \%$} \\
\hline & & \\
\hline \multirow{2}{*}{$\begin{array}{l}\text { Biaya Operasional Pendapatan Operasional (BOPO) } \\
\text { merupakan rasio yang digunakan untuk mengukur } \\
\text { manajemen bank dalam mengendalikan biaya operasional } \\
\text { terhadap pendapatan oprasional. (Pandia,2012:72) }\end{array}$} & \multirow[t]{2}{*}{ Rasio } & \multirow{2}{*}{$\mathrm{BOPO}=\frac{\text { Biaya Operasional }}{\text { Pendapatan Operasional }} \times 100 \%$} \\
\hline & & \\
\hline \multirow{2}{*}{$\begin{array}{l}\text { Loan to Deposit Ratio (LDR) adalah perbandingan antara } \\
\text { kredit yang diberikan terhadap dana pihak ketiga. (Pandia, } \\
\text { 2012:173) }\end{array}$} & \multirow[t]{2}{*}{ Rasio } & \multirow{2}{*}{$\mathrm{LDR}=\frac{\text { Jumlah Kredit yang Diberikan }}{\text { Jumlah Dana Pihak Ketiga }} \times 100 \%$} \\
\hline & & \\
\hline \multicolumn{3}{|c|}{ Variabel Dependen $(Y)$} \\
\hline $\begin{array}{l}\text { Menurut Darsono dan Ashari (2005:101) financial distress } \\
\text { dapat diartikan sebagai ketidakmampuan perusahaan } \\
\text { untuk membayar kewajiban keuangan pada saat jatuh } \\
\text { tempo yang dapat menyebabkan kebangkrutan perusahaan. }\end{array}$ & Nominal & $\begin{array}{l}0=\text { Financial distress } \\
1=\text { Non Financial distress }\end{array}$ \\
\hline
\end{tabular}

Sumber: Data yang telah diolah,2017 